\title{
Master Students' Perceptions of Blended Learning in the Process of Studying English during COVID 19 Pandemic in Ukraine
}

\author{
Vita Bezliudna1', Iryna Shcherban², Olena Kolomiyets³, Volodymyr Mykolaiko4, \& Roman \\ Bezliudnyi ${ }^{5}$ \\ 1Pavlo Tychyna Uman State Pedagogical University, Ukraine. Email: v.bezludna@udpu.edu.ua. \\ ORCID 0000-0002-4333-9026. \\ 2Pavlo Tychyna Uman State Pedagogical University, Ukraine. Email: i.shcherban@udpu.edu.ua. \\ ORCID 0000-0002-9918-7711. \\ 3Pavlo Tychyna Uman State Pedagogical University, Ukraine. Email: kolmiyets@udpu.edu.ua. \\ ORCID 0000-0003-4169-7089 \\ ${ }^{4}$ Pavlo Tychyna Uman State Pedagogical University, Ukraine. Email: v.mykolaiko@udpu.edu.ua. \\ ORCID 0000-0002-0515-1241 \\ ${ }^{5}$ Pavlo Tychyna Uman State Pedagogical University, Ukraine. Email: r.o.bezliudnyi@udpu.edu.ua. \\ ORCID 0000-0002-5687-2794
}

\begin{abstract}
The academic year 2020/2021 in higher education institutions in Ukraine began under the conditions of deteriorating epidemiological situation caused by the spread of Covid-19 pandemic. Students' training was recommended to be carried out in the form of distance learning or blended learning. This research aims to analyse Master students' perceptions of blended learning in the process of studying English in higher education institution. The study presents the integrated course "Foreign Language for Specific Purposes (English)" developed for Master students of Pavlo Tychyna Uman State Pedagogical University. The experiment involves 84 respondents. The empirical basis of the study is the results obtained during threemonths' work with master students. Theoretical, empirical and statistical methods are used to conduct the study. The study investigates benefits and challenges of blended learning in studying English by Master students. The results of the questionnaire indicate the quality of teaching the course "Foreign Language for Specific Purposes (English)" as moderately positive and point out blended learning as essential streamlined approach for creating effective learning experiences. The obtained results confirm the favourable Master students' perceptions of blended learning in studying English during Covid-19 pandemic. Based on the findings of the study, which indicate benefits and challenges of blended learning in studying English, the authors give recommendations to improve the course "Foreign Language for Specific Purposes (English)".
\end{abstract}

Keywords: Master Students, Blended Learning, English, Higher Education Institution

\section{Introduction}

The problem of choosing the most effective innovative methods and technologies in higher education institutions (HEIs) has always been significant and relevant, especially today, as Covid-

This Open Access article is published under a Creative Commons Attribution Non-Commercial 4.0 International License (http://creativecommons.org/licenses/by-nc/4.0/), which permits non-commercial re-use, distribution, and reproduction in any medium, provided the original work is properly cited. For citation use the DOI. For commercial re-use, please contact editor@rupkatha.com. 
19 pandemic has badly affected most countries, including Ukraine. The changing reality leads to the changing mission of education, in particular higher education.

On March 12, 2020, the Cabinet of Ministers of Ukraine had to introduce quarantine measures for a certain period of time, which prohibited students from attending education institutions all over the country (The Cabinet of Ministers of Ukraine. Resolution No. 262, Resolution No. 211). In such circumstances, the heads of education and higher education institutions were obliged to ensure the organization of the educational process on the basis of distance learning technologies for the period of quarantine (Ministry of Education and Science of Ukraine. Order No. 406.). Under the Higher Education Act, HEIs obtained a level of autonomy and self-government allowing them to determine independently the forms of education and organization of the educational process. Universities were given the option to decide when to start and what kind of educational process to choose in the upcoming academic year (Government portal).

The academic year 2020/2021 in HEIs began under the conditions of deteriorating epidemiological situation caused by the spread of Covid-19 pandemic. According to the letter of the Ministry of Education and Science № 1/9-576 (October 12, 2020) Regarding the temporary transition to distance learning it was recommended to introduce distance learning in HEIs (Ministry of Education and Science of Ukraine. Letter № 1/9-576). From November 16, 2020, training in HEIs was recommended to be carried out in the form of blended learning $(\mathrm{BL})$ with the introduction of appropriate changes to the schedule of educational process, taking into account the epidemic situation in each specific region and educational institution (Ministry of Education and Science of Ukraine. Recommendation to conduct blended training). Ukrainian HEIs were advised to determine independently how to organize the study process and which technology to use, so that each student could complete the academic year (Ukrainian Higher Education responds to the COVID-19 challenges).

\section{Literature Review}

\subsection{The Concept of Blended Learning}

The problem of blended learning is widely discussed by many foreign and Ukrainian scientists, such as Ardianti (2020), Buhaichuk (2016), Christensen (2013), Horn (2013), Kostina (2010), Kukharenko (2016), Oliver (2005), Shcheglova (2016), Spirin (2020), Staker (2012), Zelenskyi (2020). The scientists pay attention to the implementation of $B L$ in educational process, development of integrated educational programs and courses, search of innovative forms and methods of teaching, improvement of conditions for mastering a foreign language by individualization of learning, identification of BL means, determination of the role and place of $B L$ in the educational process and estimation of their use in training, etc.

The BL method is a well-known approach in academic education. In most of its profitable applications, face-to-face contacts between students and the teacher as well as students with each other in groups are important elements in the organization of classes (Ożadowicz, 2020).

Hoic-Bozic explains that BL incorporates online and traditional learning environments, technologies and digital media for learning content delivery, taking into account various teaching and learning methods (both online and traditional ones). Moreover, group and individual learning activities are considered for effective BL implementation with synchronous and asynchronous 
interactions between all participants in the learning and teaching processes. That approach allows the building of a variety of frameworks and structures for courses with high commitment of students and active, mentoring role of teachers and lecturers (Hoic-Bozic, 2009).

Krismadinata considers BL as learning that combines offline classes with online learning. It can create flexible learning and can be done at any time in various places where there are interaction facilities and activities in it (Krismadinata, 2020). The application of BL has its own proportion between offline and online. Before implementing BL in professional education, it is necessary to pay attention to the things that are needed in the implementation of $B \mathrm{~L}$, such as the normal development of the BL model, application of topology, and knowledge of the characteristics of the institution. Christensen notes that the main idea of $B L$ is not that part of learning takes place online, but that students have the opportunity to control their pace, time and place of study (Christensen, 2013).

Our study is based on the opinion that BL is especially effective in learning foreign languages, as it includes live communication, online reading, watching videos, visual "cramming" of words, helps students to organize and to plan work individually, to acquire and to analyse knowledge independently, to seek and to select information, to make decisions, to develop project presentation skills, to engage in self-education (Bezliudnyi, 2019).

There are more than dozen models of BL. They differ in accents, purpose, goals, costs, and others. Simultaneously, the classification of the American researcher Horn is generally accepted, which identifies six BL models: Rotation Model, Flex Model, Self-Blend, The Enriched-Virtual Model, Online Lab and Online Driver Model (Horn, 2011). Teachers in Pavlo Tychyna Uman State Pedagogical University predominantly use Flex and Online Driver Models. According to Flex Model the training course is mainly conducted online. The teacher coordinates the activities of students through the network. «Live» contacts occur as needed. Online Driver Model provides that learning process take place online through an educational platform. Contacts with the teacher are also carried out in the mode of remote access; face-to-face classes and meetings are not provided but can be added as needed. Teachers in Pavlo Tychyna Uman State Pedagogical University mostly use ZOOM, Google Meet and Google Classroom in their practice, but Moodle is predominantly used for master students as most of them have part-time job and have difficulties with attending classes online.

\subsection{Incorporation of $B L$ in Moodle Course}

As a result of the analysis of Internet resources, it is determined that the vast majority (86\%) of Ukrainian HEIs, which provide training in pedagogical specialties, use Moodle. Pavlo Tychyna Uman State Pedagogical University is among them (Mintii, 2020). During the first semester of academic year 2020/2021 the most optimal learning technologies used in Pavlo Tychyna Uman State Pedagogical University are distance learning and BL. BL is especially useful in foreign language teaching, as it provides the opportunity for live communication (Beck, 2020). Thus, the teachers of the university faced the task to design courses and distribute the educational material for online classes, face-to-face classes and group work.

A rational solution to the task of studying English by Master students in the university was the designing of the course "Foreign Language for Specific Purposes (English)" on the Moodle 
platform. The course itself is based on BL approach (online and face-to-face classes) that allows teachers and students to use different techniques and methods of processing educational material and to structure students' learning. In particular, the use of $B L$ in the process of studying the course "Foreign Language for Specific Purposes (English)" gives Master students the possibility to perform practical and creative tasks, use reference materials, audio and video materials of the Internet, take module and control tests, etc.

\section{Significance of the Research}

The significance of this paper is connected with the fact that foreign languages, which are difficult to learn during the quarantine period in higher education institutions, plays an extremely important role in the formation of future specialists. After the lockdown and now - during adoptive quarantine - HEIs in Ukraine along with standard of foreign language learning technologies actively use innovative technologies in teaching practices, predominantly BL. Though the previous studies dealt with using of $\mathrm{BL}$ in education institutions and searching of innovative forms and methods of teaching English however there is no applied research that would comprehensively and substantively analyse Master students' perceptions of BL in the process of studying English in higher education institutions during Covid-19 pandemic in Ukraine.

\section{Research Methodology}

\subsection{Methods and Materials}

To conduct the study, a set of scientific, theoretical, empirical and statistical methods was used, namely: synthesis, conceptualization of theoretical practical knowledge, systematic analysis of documents and scientific investigations of the problem, classification etc. Descriptive statistics were employed, such as frequency, percentage, mean scores, and weighted means. A survey was used to collect and analyse the information from respondents. Information was collected, interpreted, analysed, and statistically treated.

This study was conducted at the Faculty of Physics, Mathematics and Informatics of Pavlo Tychyna Uman State Pedagogical University. The target respondents were Master students with bachelor degree and have experience of studying English during the 1st and 2nd years of study before implementing BL caused by Covid-19 pandemic in Ukraine. The total number of the respondents was 84 .

\subsection{Research Objectives}

The aim of the study is to analyse Master students' perceptions of BL in the process of studying English in HEIs in Ukraine (on the example of Pavlo Tychyna Uman State Pedagogical University, Faculty of Physics, Mathematics and Informatics). To attain the aim, the following objectives are stated in the article:

1) to find out the benefits and challenges of $B L$ in the process of studying English;

2) to give the assessment of quality of teaching the course "Foreign Language for Specific Purposes (English)" based on BL; 
5 Master Students' Perceptions of Blended Learning in the Process of Studying English

during COVID 19 Pandemic in Ukraine

3) to identify the impact of BL on the Master students' studying of the course "Foreign Language for Specific Purposes (English)";

4) to find out whether the course needs improvement.

\subsection{Research Instruments}

To gather pertinent data and information needed for the study, the researchers used a questionnaire, which contained open-ended questions (3,5), closed multivariate questions (1), closed alternative scale questions $(2,4,6)$ and semi-closed questions $(7,8)$.

$\mathrm{BL}$ dimensions such as assessment of benefits, challenges and the course quality were rated using a 5-point Likert Scale. Each criterion was measured on a 5-point scale and the description used in assessing the given categories such as 5: Very high assessment; 4: High assessment; 3 : Average assessment; 2: Low assessment; and 1: Very low assessment. The means of the weighted responses were interpreted along the following scale and description (Table 1).

Table 1. Arbitrary Scale

\begin{tabular}{|c|c|c|}
\hline Rating & Range & Verbal Interpretation \\
\hline 5 & $4.01-5.00$ & Very high assessment \\
\hline 4 & $3.50-4.00$ & High assessment \\
\hline 3 & $2.50-3.49$ & Average assessment \\
\hline 2 & $1.50-2.49$ & Low assessment \\
\hline 1 & $1.00-1.49$ & Very low assessment \\
\hline
\end{tabular}

Summary of the data on the number of Master students, their educational degree, specialty and duration of study are presented in Table 2.

Table 2. Distribution of Master students by specialities

\begin{tabular}{|c|c|c|c|}
\hline Specialty & Educational degree & Duration of study & Number of students \\
\hline $\begin{array}{c}\text { Secondary education } \\
\text { (Informatics) }\end{array}$ & Master & 1 year 4 months & 29 \\
\hline $\begin{array}{c}\text { Secondary education } \\
\text { (Informatics) }\end{array}$ & Master & 1 year 9 months & 14 \\
\hline $\begin{array}{c}\text { Secondary education } \\
\text { (Mathematics. } \\
\text { Informatics) }\end{array}$ & Master & 1 year 4 months & 27 \\
\hline $\begin{array}{c}\text { Secondary education } \\
\text { (Mathematics) }\end{array}$ & Master & 1 year 9 months & 5 \\
\hline
\end{tabular}




\begin{tabular}{|c|c|c|c|}
\hline $\begin{array}{c}\text { Secondary education } \\
\text { (Physics. Informatics) }\end{array}$ & Master & 1 year 4 months & 4 \\
\hline $\begin{array}{c}\text { Secondary education } \\
\text { (Natural Sciences) }\end{array}$ & Master & 1 year 9 months & 5 \\
\hline Total & & & 84 \\
\hline
\end{tabular}

\section{Research Results}

The study was conducted from October to December 2020. The questionnaire was sent to the survey participants in electronic form by e-mail. The purpose and structure of the survey were explained to the students. The questionnaire was presented to the respondents in Ukrainian.

The research procedure included the following stages: questionnaire emailing; collection of survey; processing and verification of the integrity and reliability of survey data.

The data were collected using a questionnaire prepared on the basis of an objective analysis of the literature related to the field. The questionnaire was designed to determine students' perceptions on the use of BL in the process of studying English. The questionnaire was intended to identify the benefits of $B L$ in the process of studying English (questions 1, 2, 3); the challenges of $B L$ in the process of studying English (questions 4,5); impact of BL on the master students' studying of the course "Foreign Language for Specific Purposes (English)" (questions 6, 7, 8).

Answering the question №1: "Does BL facilitate the acquisition of the material of the course "Foreign Language for Specific Purposes (English)?" 80\% (67) of students answered "yes", 19\% (16) of students found it difficult to answer and only 1\% (1) answered "no".

Question №2 was aimed at determining the assessment of the benefits of BL and its comparison with traditional learning (Table 3).

Table 3. Assessment of BL benefits

\begin{tabular}{|c|c|c|c|}
\hline № & Items & Mean & Verbal Interpretation \\
\hline 1 & Providing an online availability of content & 4.16 & Very high assessment \\
\hline 2 & $\begin{array}{c}\text { Providing richer and more interactive learning } \\
\text { experiences }\end{array}$ & 4.10 & Very high assessment \\
\hline 3 & $\begin{array}{c}\text { Providing an extension of learning beyond the } \\
\text { classrooms }\end{array}$ & 3.74 & High assessment \\
\hline 4 & $\begin{array}{c}\text { Providing an individualized support for the } \\
\text { students through individual connection via } \\
\text { various tech tools }\end{array}$ & 3.40 & Average assessment \\
\hline 5 & Providing more time for collaboration with the & 3.45 & Average assessment \\
\hline
\end{tabular}




\begin{tabular}{|c|c|c|c|}
\hline 6 & students and teachers. & & \\
\hline 6 & $\begin{array}{c}\text { Providing a flexibility to incorporate various } \\
\text { curricular and institutional needs, goals and } \\
\text { priorities }\end{array}$ & 4.15 & Very high assessment \\
\hline \multirow{2}{*}{ Weighted Mean } & 3.8 & High assessment \\
\hline
\end{tabular}

It can be understood from the table that generally the respondents assessed $\mathrm{BL}$ benefits high (WM: 3.8). Considerably, item №1, which states that "Providing an online availability of content" (MS: 4.16), got the highest mean score. This is to tell that students deeply evaluate the access to studying material at anytime and anywhere. On the other hand, item № 4 says, "Providing an individualized support for the students through individual connection via various tech tools" (MS: 3.40) got the lowest. This means that students' assessment suggests that teachers' attitude to students' support while BL must be improved.

Students were asked to give their own version of $\mathrm{BL}$ benefits (question №3). Among the advantages of BL of English language $72 \%$ (60) students named the opportunity to study at home, $58 \%$ (49) of respondents noted a flexible schedule of study, 39\% (33) of respondents emphasized the possibility of gaining experience in self-study, $49 \%$ (41) people noticed time savings in the process of learning English, 14\% (12) agreed that BL increases the interaction between a tutor and a student and $17 \%$ (14) students did not notice much benefit (Fig. 1).

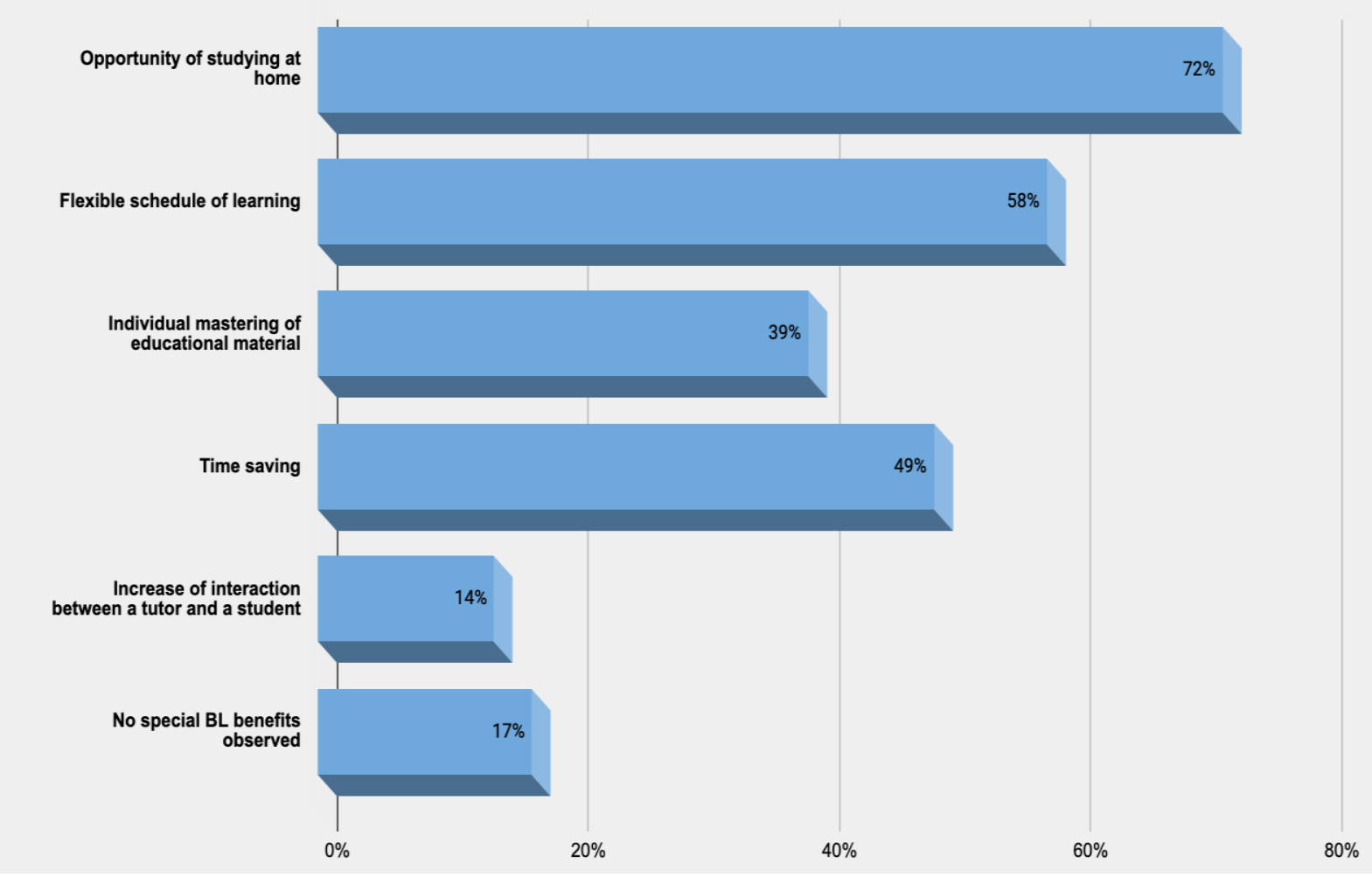

Figure 1. Benefits of $B L$ 
Table 4. Assessment of BL challenges

\begin{tabular}{|c|c|c|c|}
\hline No & Items & Mean & $\begin{array}{c}\text { Verbal } \\
\text { Interpretation }\end{array}$ \\
\hline 1 & Having skills of using the e-learning technology & 4.15 & $\begin{array}{c}\text { Very high } \\
\text { assessment }\end{array}$ \\
\hline 2 & $\begin{array}{c}\text { Inequality of technological support facilities and infrastructures } \\
\text { Very high } \\
\text { assessment }\end{array}$ & 4.74 & $\begin{array}{c}\text { Very high } \\
\text { assessment }\end{array}$ \\
\hline 3 & $\begin{array}{c}\text { Spending time in developing e-learning skills, especially during } \\
\text { the initial implementation period }\end{array}$ & 4.10 & High assessment \\
\hline 5 & $\begin{array}{r}\text { Redefining the role of the facilitator while managing and } \\
\text { monitoring participant progress }\end{array}$ & 3.82 & High assessment \\
\hline 6 & Ensuring all the elements of the blend are coordinated \\
\hline 4 & 4.15 & $\begin{array}{c}\text { Very high } \\
\text { assessment }\end{array}$ \\
\hline & $\begin{array}{r}\text { Weighted Mean } \\
\text { Very high }\end{array}$ \\
\hline
\end{tabular}

Question №4 was intended to assess the challenges identified in the process of studying English by master students (Table 4).

Generally, the assessment of BL challenges gained high assessment. Item № 2, which states that "inequality of technological support facilities and infrastructures" is one of BL challenges, got the highest mean score. This is to tell that adopting BL for remote areas because of the capacity and quality of the internet in these areas is limited. Students find sending and acquiring information via email, blogs, among others necessary as revealed by the high assessment of this item with a mean score of 4.74 . It is essential to note that the accessibility and availability of electronic resources must be examined to maximize the use of $B L$ in effect on the learning outcomes of the respondents. The findings supported the standpoint that teaching English through BL should be enhanced and updated to be able to deliver instruction more efficiently and more effectively in a BL environment.

Students were asked to provide their own list of possible challenges of $B L$ of English language (question № 5). The most common answer options are systematized and presented in Figure 5. The majority of respondents, namely $63 \%$ (53) believed that BL did not always show a real level of knowledge, 31\% (26) of respondents pointed out some technical problems during the organization of $\mathrm{BL}, 18 \%$ (15) of students indicated some difficulties in educational self-discipline, $20 \%$ (14) of respondents did not show any special difficulties during BL, but $27 \%$ (23) emphasized the complexity of the content of the course and noted that BL increased social isolation (Fig. 2). 
The question № 6 is aimed at giving the assessment of the quality of teaching the course "Foreign Language for Specific Purposes (English)" based on BL (Table 5).

Table 5 shows that items № 2, 5 "Using various learning materials that are accessible and usable" and "Strengthening tutorials/assistance services", and item № 6 "Ensuring a smooth interpersonal, professional relationship among students and their tutors" (MS: 3.00) got the lowest mean score. This means that the respondents believe that it is necessary to maximize $\mathrm{BL}$ as a tool of teaching English as well as the use of various learning materials like print (e.g.: books, magazines, journals, etc.) and non-print media (e.g.: CD's, videos, etc.) in BL must be reinforced. Teachers should also be retooled to utilize and maximize BL towards the quality of master students' education. Considerably, item №7, which states that "Promoting quality learning to realize potentials to be able to be more productive in the workplace" (MS: 4.10), got the highest mean score. This means that the quality of teaching the course "Foreign Language for Specific Purposes (English)" based on $\mathrm{BL}$ is not high but moderately positive. $\mathrm{BL}$ is essential to the success of the course that allows students to increase their knowledge in English.

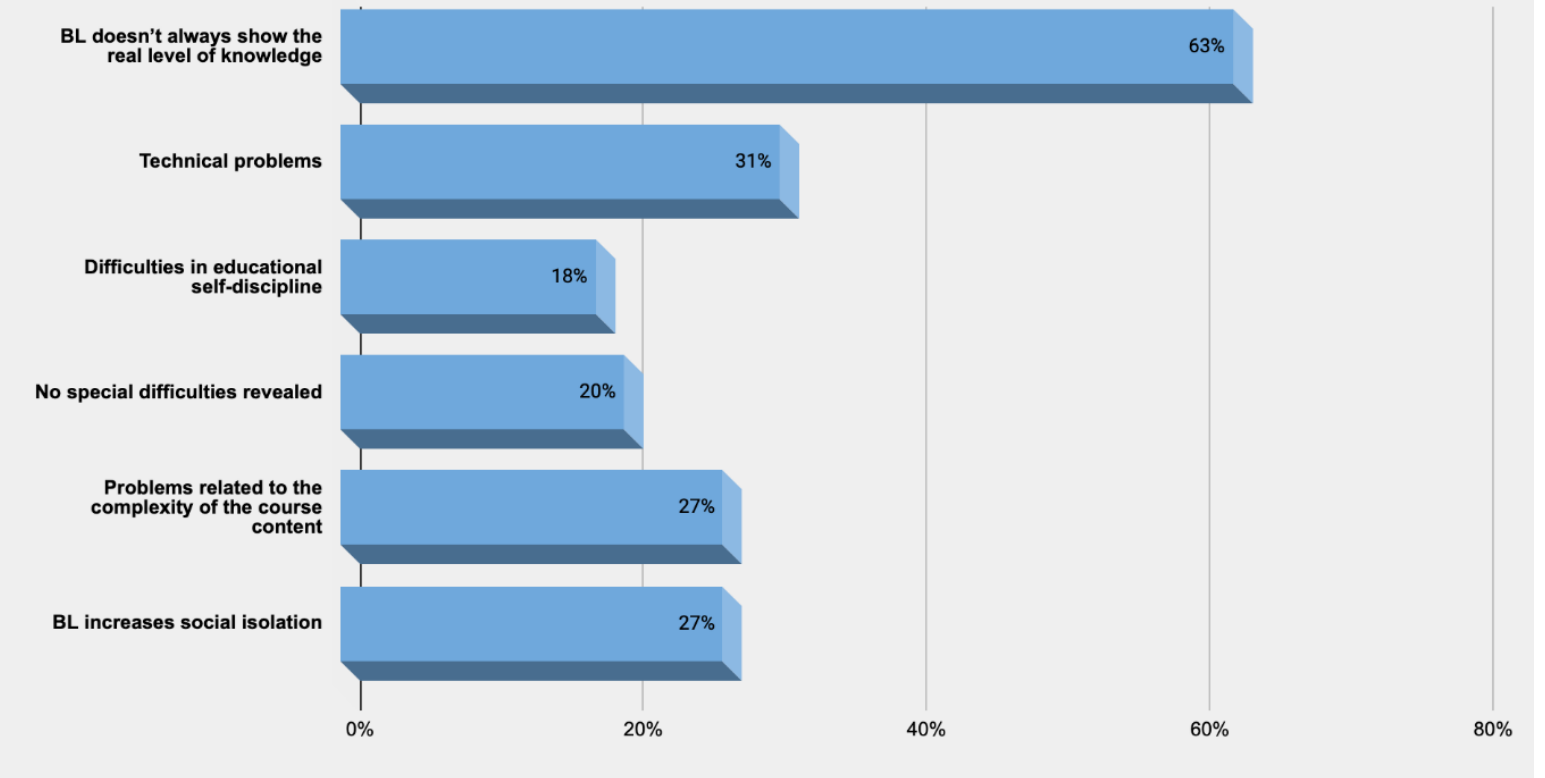

Figure 2. BL challenges

Table 5. Assessment of the course quality based on BL

\begin{tabular}{|c|c|c|c|}
\hline No & Items & Mean & $\begin{array}{c}\text { Verbal } \\
\text { Interpretation }\end{array}$ \\
\hline 1 & $\begin{array}{c}\text { Providing a learning design that is suitable for student } \\
\text { activities }\end{array}$ & 3.95 & High assessment \\
\hline 2 & $\begin{array}{c}\text { Using various learning materials that are accessible and } \\
\text { usable }\end{array}$ & 2.90 & Average assessment \\
\hline
\end{tabular}




\begin{tabular}{|c|c|c|c|}
\hline 3 & $\begin{array}{c}\text { Providing learning outcomes and objectives that are } \\
\text { realistic }\end{array}$ & 3.80 & High assessment \\
\hline 4 & Providing user-friendly electronic resources & 3.85 & High assessment \\
\hline 5 & Strengthening tutorials/assistance services & 2.90 & Average assessment \\
\hline 6 & $\begin{array}{c}\text { Ensuring a smooth interpersonal, professional } \\
\text { relationship among students and their tutors }\end{array}$ & 3.00 & Average assessment \\
\hline 7 & $\begin{array}{c}\text { Promoting quality learning to realize potentials to be } \\
\text { able to be more productive in the workplace }\end{array}$ & 4.10 & Very high assessment \\
\hline & Weighted Mean & 3.50 & High assessment \\
\hline
\end{tabular}

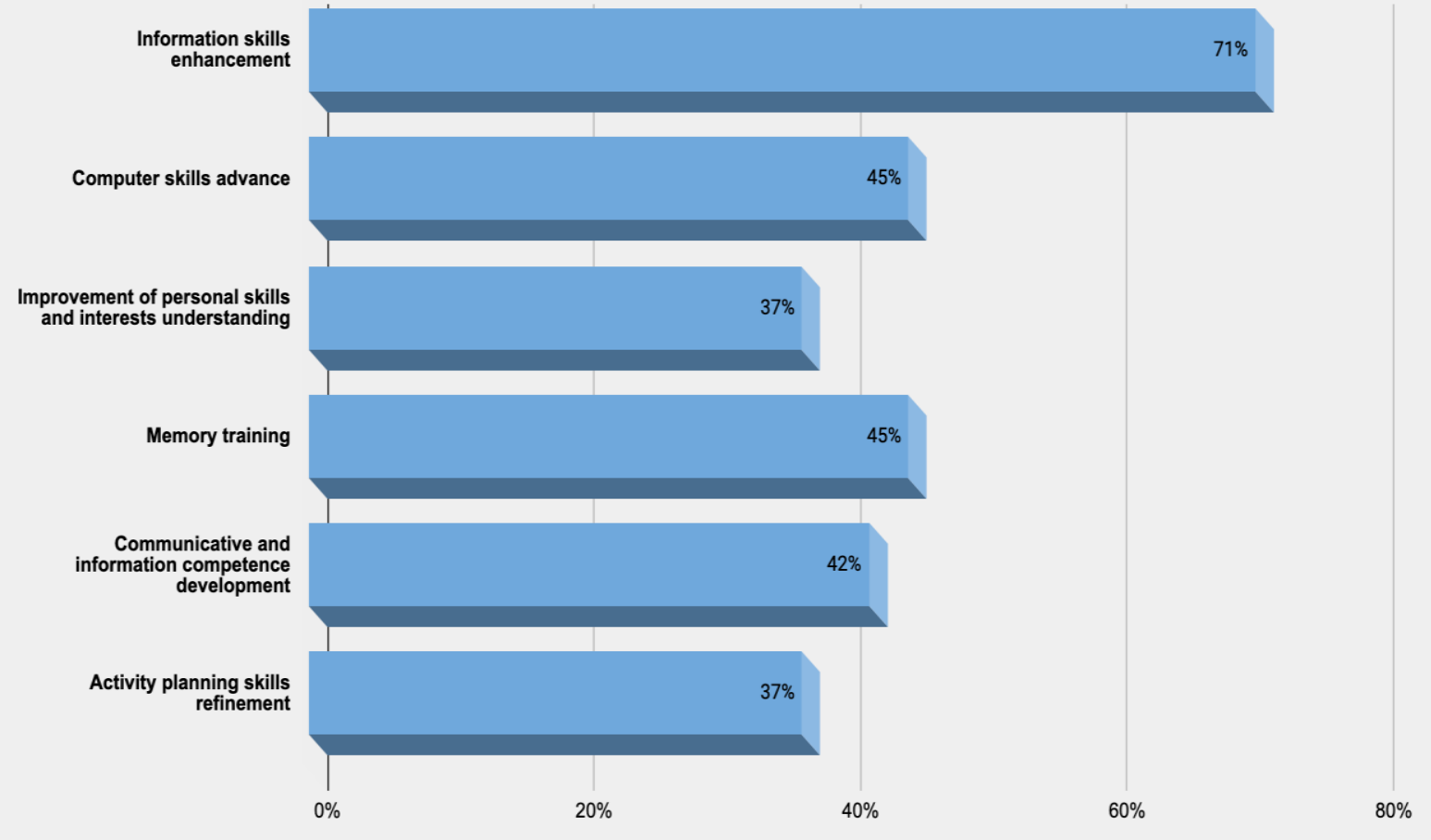

Figure 3. The impact of BL on the Master students' studying of the course "Foreign Language for Specific Purposes (English)"

One of the objectives of our research was to identify the impact of BL on the Master students' studying of the course "Foreign Language for Specific Purposes (English)" (question №7). 71\% (60) of respondents noticed an enhancement in general skills in working with information, $45 \%$ (38) of respondents rated the advance of their computer skills, $37 \%$ (31) of the respondents were convinced that their understanding of their skills and interests improved, and 45\% (38) of respondents mentioned constant memory training during $\mathrm{BL}, 42 \%$ (35) of students agreed that $\mathrm{BL}$ developed their communicative and informational competence, and 37\% (31) confirmed the refinement of their activity planning skills (Fig. 3). 


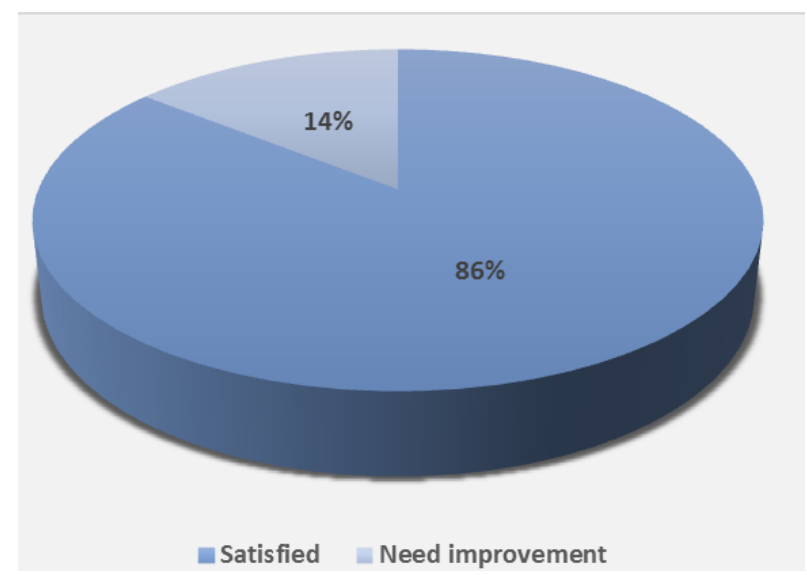

Figure 4. Master students' perceptions of the course "Foreign Language for Specific Purposes (English)"

The final question of the study was to find out whether the course "Foreign Language for Specific Purposes (English)" needed to be improved from the point of view of Master students (Fig. 4).

Answering the question № 8: "Would you like to improve the course?" 86\% (72) of respondents noted that they were satisfied with the course and only $14 \%$ (12) indicated that the course needed to be improved with the use of interactive classes, online conferences and social networking applications that promote studying the course. The obtained results show that the majority of students perceived the course "Foreign Language for Specific Purposes (English)" positively.

\section{Discussion}

The theoretical analysis of the study shows that the use of effective innovative methods and technologies in HEIs is significant and relevant during Covid-19 pandemic. BL has gained strength and space in higher education, and that it is increasingly relevant in the current way of life. This sensible and practical option benefits the people who need it (Harry Clavijo Suntura, 2021).

Results of the study have revealed the benefits of $B L$ in the process of studying English: flexible schedule and pace of study, the opportunity to study at home, the opportunity to gain experience in mastering the material, saving time while learning English, the ability to share ideas with their classmates on forums. But at the same time in studying English master students faced some challenges: inequality of technological support facilities and infrastructures by separate technical problems, inability to show the real level of student knowledge, the complexity of the course content, poor motivation to learning, increasing social isolation, internet connection instability, etc. The study was conducted to understand, whether the course of "Foreign Language for Specific Purposes (English)" needed to be improved from the point of view of Master students. The results of the research show that despite the fact that most students highly appreciated the organization of the BL of the designed course, they expressed the need to increase the number of interactive classes, online conferences and the require of revision and improvements of social networking applications use. The results of the questionnaire show that the assessment of course quality got the lowest indices. We agree with suggestions of Lebedev to pay special attention to the correspondence of materials to the subject area of knowledge during English for Specific Purposes 
training, and to highlight the skills that will be most demanded in the labour market. But in general the results indicate that the quality of teaching the course "Foreign Language for Specific Purposes (English)" is not high but moderately positive and BL is essential to the success of the course (Lebedev, 2020).

A key finding of the current study is that Master students have a generally positive perception of $\mathrm{BL}$ in the process of studying English in HEIs. The results of the conducted research are related to the study of Drysdale and Ja'ashan which conclude that in general the students' perceptions and attitudes towards BL in HEIs are positive (Drysdale, 2013; Ja'ashan, 2015).

Another research, conducted by Aji on the results of students' interviews, also states that there were some advantages and challenges in studying through blended learning (Aji, 2020). So, the use of $B L$ in higher education institutions confirms previous researches in this field and makes it possible for Master students to learn English not only in the classroom but outside the University according to their time and speed of learning.

\section{Conclusion and Recommendations}

As described above during Covid-19 pandemic BL allows aster students to study English in HEIs taking advantages of both online and face-to-face classes. Though $\mathrm{BL}$ is in the developmental stage in higher education of Ukraine, the results demonstrate favourable Master students' perceptions of its implementation. At the same time, the obtained results show that there are some challenges and obstacles that the academic staff of the University should take into consideration in order to improve the course "Foreign Language for Specific Purposes (English)" on Moodle platform and make the process of studying English more effective for Master students.

To improve the quality of the course "Foreign Language for Specific Purposes (English)" the researches recommend: to conduct lessons interactive and authentic, combining live interaction among Master students and teachers with interactive multimedia materials that support welldesigned assignments and projects that students may complete at home; to combine synchronous activities in which Master students meet online or in person with their teachers and classmates with asynchronous activities in which Master students engage deeply with both the subject matter and groups of peers to combine using static textbooks or worksheets with interactive learning materials as well as provide choice and control by offering a variety of tasks.

\section{REFERENCES}

[1] The Cabinet of Ministers of Ukraine. Resolution No. 262. On Amendments to the Resolution of the Cabinet of Ministers of Ukraine of March 11. No. 211. Apr. 08. 2020. https://www.kmu.gov.ua/npas/pro-vnesennya-zmin-do-p ostanovi-ka-a262 (accessed Apr. 21, 2020).

[2] Cabinet of Ministers of Ukraine. Resolution No. 211. On Prevention of Spreading of COVID-19 Coronavirus in Ukraine. March 11, 2020. https://www.kmu.gov.ua/npas/pro-zapobigannya-poshim 110320rennyu-na-territoriyi-ukrayini-koronavirusu- covid-19 (accessed Apr. 21, 2020).

[3] Ministry of Education and Science of Ukraine. Order No. 406. On Organizational Measures to Prevent the Spread of Coronavirus COVID-19. March 16, 2020. https://mon.gov.ua/ua/npa/pro-organizacijnizahod i-dlya-zapobigannya-poshirennyu-koronavirusu-s-ovid-19 (accessed Apr. 21, 2020). 
[4] Government portal. https://www.kmu.gov.ua/en/news/denis-shmigal-universiteti-mozhut-samiviznachati-koli-i-v-yakij-formi-yim-pochinati-osvitnij-proces-u-novomu-navchalnomu-roci (accessed Dec. 15, 2020).

[5] Ministry of Education and Science of Ukraine. Letter № 1/9-576. Regarding the temporary transition to distance learning. October 12, 2020. http://ru.osvita.ua/legislation/Vishya_osvita/76975/ (accessed Oct. 18, 2020).

[6] Ministry of Education and Science of Ukraine. Recommendation to conduct blended training in institutions of higher and vocational education. November 13, 2020. https://mon.gov.ua/ua/news/mon-rekomenduye-iz-16-listopada-provoditi-navchannya-v-zakladahvishoyi-ta-fahovoyi-peredvishoyi-osviti-za-zmishanoyu-formoyu (accessed Nov. 19, 2020).

[7] Ukrainian Higher Education responds to the COVID-19 challenges. https://supporthere.org/news/ukrainian-higher-education-responds (accessed Dec. 10, 2020).

[8] Ardianti, S. et al. (2020) The Impact of the Use of STEM Education Approach on the Blended Learning to Improve Student's Critical Thinking Skills. Universal Journal of Educational Research, 8, 3B, 24-32. DOI: 10.13189/ujer.2020.08150

[9] Buhaichuk, K. (2016) Blended learning: theoretical implementation in educational process of higher educational institutions. Information Technologies and Learning Tools, 54, 4, 1-18. DOI: 10.33407/itlt.v54i4.1434

[10] Christensen, C., Horn, M., Staker, H. (2013) Is K-12 Blended Learning Disruptive? An introduction of the theory of hybrids. San Francisco CA, USA: Clayton Christensen Institute. https://www.christenseninstitute.org/ publications/hybrids/ (accessed June 25, 2020).

[11] Kostina, Ye. (2010) Blended learning model (Blended Learning) and its use in teaching of foreign languages. Proceedings of the higher educational institutions. Series: Humanities, 1, 2, 141-144. https://www.isuct.ru/e-publ/gum/sites/ru.epubl.gum/files/2010/t01n02/humscience_2010_t01n02_141.pdf (accessed June 2, 2020).

[12] Kukharenko, V. et al. (2016) Theory and practice of blended learning. Kharkiv, Ukraine: "Miskdruk" NTU "KhPI". http://repository.kpi.kharkov.ua/bitstream/KhPIPress/23536/3/Kukharenko_Teoriia_ta_praktyka_2016.pdf (accessed July 25, 2020).

[13] Oliver, M., Trigwell, K. (2005) Can 'Blended Learning' Be Redeemed?, E-Learning, 2, 1, 17-26. http://journals.sagepub.com/ (accessed June 25, 2020).

[14] Shcheglova, A. (2016) The Importance of Project-Based Method for Formation and Improving of Foreign Communicative Competence in Blended Learning. Information Technologies and Learning Tools, 53, 3, 142. DOI: 10.33407/itlt.v53i3.1381

[15] Spirin, O., Kolos, K. (2020) Technology for organization of distance learning for students in quarantine conditions on the basis of the Moodle platform. Information Technologies and Learning Tools. 79(5). 29-58. DOI:10.33407/itlt.v79i5.4090

[16] Staker, M. (2012.) Classifying K-12 Blended Learning. Innosight Institute. DOI: 10.13189/ujer.2020.080507

[17] Zelenskyi, M., Nesterenko, I., Volovik, N., Mytsenko, D. (2020) Blended learning technologies for a foreign language teaching the students of non-philological majors. Herald of Kiev Institute of Business and Technology. 44(2). 4-10. DOI: https://doi.org/10.37203/kibit.2020.44.01

[18] Ożadowicz, A. (2020) Modified Blended Learning in Engineering Higher Education during the COVID- 
19 Lockdown - Building Automation Courses Case Study. Educ. Sci10. 292. DOI: 10.3390/educsci10100292 (accessed June 20, 2020).

[19] Hoic-Bozic, N., Mornar, V., Boticki, I. (2009) A Blended Learning Approach to Course Design and Implementation. IEEE Trans. Educ., 52, 19-30.

[20] Krismadinata, K. et al. (2020) Blended Learning as Instructional Model in Vocational Education: Literature Review. Universal Journal of Educational Research. 8, 11B, 5801-5815. DOI: 10.13189/ujer.2020.082214

[21] Bezliudnyi, O., Bezliudna, V., Shcherban, I., Komar, O. (2019) The experience of using the technology of blended learning in English classes in institutions of higher pedagogical education. Information technology and learning tools. 73. 5. 86-100. DOI: 10.33407/itlt.v73i5.2669

[22] Horn, M., Staker, H. (2011) The Rise of K-12 Blended Learning", Innosight Institute - Charter School Growth Fund - Public Impact. 17.

[23] Pavlo Tychyna Uman State Pedagogical University. https://moodle.dls.udpu.edu.ua.

[24] Mintii, I., Shokaliuk, S., Vakaliuk, T., Merzlykin, O., Mintii, M. (2020) Development of a Standard Moodle Course to Optimize the Teacher's Work in Distance Education. Universal Journal of Educational Research. 8, 12, 6659-6666. DOI: 10.13189/ujer.2020.081230.

[25] Beck, G., Tsaryk, O., Rybina, N. (2020) Teaching and assessment strategies in online foreign languages distance learning. International Scientific and Practical Conference "Professional and communication culture of the future doctor: linguistic, pedagogical and philosophical aspects". 2, 6-13.

[26] Harry Clavijo Suntura, Omar Abreu Valdivia, Maribel Rosero Rosero, Gloria Aragón Cuamacás (2021) Blended Learning in Law School at Northern Technical University in Ibarra, Imbabura, Ecuador, Universal Journal of Educational Research, 9, 4, 792 - 798. DOI: 10.13189/ujer.2021.090411.

[27] Lebedev, A., Pinkovetskaia, I., Rozhkov M., Tsybina, L., (2020) Implementation and Peculiarities of English for Specific Purposes Course Design at Ogarev's Mordovia State University. Universal Journal of Educational Research, 8, 1, 178-182. DOI: 10.13189/ujer.2020.080122.

[28] Drysdale, J., Graham, C., Spring, K., Halverson, L. (2013) An analysis of research trends in dissertations and theses studying blended learning. Internet and Higher Education, 17(1), 90-100. DOI: 10.1016/j.iheduc.2012.11.003

[29] Ja'ashan, M. (2015) Perceptions and attitudes towards blended learning for English courses: A case study of students at University of Bisha. English Language Teaching, 8(9), 40-50. https://www.researchgate.net/publication/282514622_Perceptions_and_Attitudes_towards_Blended_Le arning_for_English_Courses_A_Case_Study_of_Students_at_University_of_Bisha. (accessed November $25,2020)$.

[30] Aji, W., Ardin, H., Arifin, M. (2020) Blended Learning During Pandemic Corona Virus: Teachers' and Students' Perceptions. IDEAS: Journal on English Language Teaching and Learning. Linguistics and Literature, [S.I.], 8, 2, 632-646. https://ejournal.iainpalopo.ac.id/index.php/ideas/article/view/1696. (accessed November 20, 2020). 